\title{
THE CURRENT TAX SITUATION OF OCCUPATIONAL PENSIONS AND PAN-EUROPEAN PENSION FUNDS
}

\author{
Gerhard Mudrack \\ Ludwigstr. 9a, 50374 Erftstadt, Germany \\ E-mail: gerhardmudrack@compuserve.de \\ Received 11 October 2006; accepted 15 December 2006
}

\begin{abstract}
The main tax obstacle to the functioning of pan-European pension funds is the exclusion from tax relief of cross-border contributions. Many Member States have eliminated this obstacle or have announced that they will do this soon. The few Member States which may wish to continue the discrimination against foreign funds may find it very difficult to explain to the ECJ why they cannot do what so many other Member States already have. The conclusion of this article is, therefore, that for most situations, the main tax obstacle for pan-European pension funds will be eliminated after the implementation date of the Pension Fund Directive, that was by 23 September 2005. The Pension Fund Directive includes the assumptions for a cross-border activity of company pension funds. Among the existing national regulations of the setting of the systems of old age pensions the member states have to allow domestic companies in line with the Pension Fund Directive to be institution of foreign pension funds, which are licensed in other member states.
\end{abstract}

Keywords: company pension funds, old age pensions, pan-European pension funds, taxation of pan-European pension funds, cross - border contributions, Pension Fund Directive.

\section{Introduction and research goal}

Tax obstacles were always seen as the main barrier to pan-European pension funds. The European Commission worked very hard to eliminate these obstacles. As a result the perspective is changing rapidly.

Commissioner Bolkestein is determined to create a Single Market for occupational pensions. Now that the Pension Fund Directive has been adopted, the pressure on the remaining tax obstacles has increased. This article discusses current developments in the pension taxation area.

\section{Jurisdiction of the European Court of Justice on political activities of the European Commission concerning occupational pensions and Pan-European pension funds}

Almost all Member States tax occupational pensions according to the EET or ETT principle. That means that the contributions by both employer and employee are tax deductible, that the investment results of the pension fund are exempt, or taxed (that is the case only in Denmark, Italy and Sweden) and that the benefits are taxed. The main reason for Member States to have such a system of deferred taxation is to encourage their citizens to save for their old age. A sideeffect is that it will help Member States to deal with the demographic time-bomb, as a State will receive tax revenues at the time when the demographic dependency ratio will be much more unfavourable. Many Member States do not allow tax deduction for pension contributions paid to a pension fund in another Member State. This effectively seals off their national markets from competition with other Member States, makes it impossible for multinationals to run panEuropean funds and constitutes a major obstacle to the free movement of workers.

To deal with this problem the European Commission issued a Communication on the elimination of tax obstacles to the cross-border provision of occupational pensions, on 19 April 2001. The Communication concluded, on the basis of the EC Treaty and the caselaw of the European Court of Justice in Luxembourg 
(ECJ), that Member States were not allowed to restrict the freedom to provide services and the free movement of workers by refusing tax deductibility for pension contributions paid to pension funds in other Member States. Since the Communication the ECJ has ruled on two cases concerning the deduction for contributions paid to foreign funds - the Danner case (Case C-136/00) on 3 October 2002, and the Skandia/Ramstedt case (Case C-422/01) on 26 June 2003 (Blomeyer, W., 2004). Both cases were referred to the ECJ by national courts. In both cases the ECJ struck down the national restrictions.

The Danner case concerned a German doctor who moved to Finland and continued to contribute to his German pension scheme. Finland refused the deduction. The ECJ ruled that Article 49 of the EC Treaty (on the freedom to provide services) precluded Finland from disallowing the deductibility if it did not at the same time preclude the taxation of the benefits paid by foreign pension providers.

The Skandia/Ramstedt case is a test case, whereby Skandia offered its director Mr Ramstedt pension policies from Skandia UK, Skandia Denmark and Skandia Germany, the only difference between those policies and a policy with Skandia Sweden being the location of the pension provider. Sweden refused deduction for the contributions paid to the foreign pension providers. The ECJ ruled unambiguously that this ran against Article49 of the EC Treaty.

The Skandia/Ramstedt ruling seems to be generally applicable to all Member States which still refuse cross-border deduction on the sole ground that the pension provider is located outside their territory. It is interesting to note that the ECJ used little time to reach its verdict. The hearing was on 30 January 2003, Advocate-General Léger issued his opinion on 30 April 2003, and the ECJ ruled on 26 June 2003.

On 5 February 2003, following-up the Pension Taxation Communication, the Commission launched five new infringement procedures, against Belgium, Spain, France, Italy and Portugal, and continued one old procedure against Denmark. All these Member States refuse any cross-border deduction for pension contributions, for both mobile workers and non-mobile workers. The five first-mentioned states received letters of formal notice, the first step in an infringement procedure, and Denmark received a reasoned opinion, the second step in an infringement procedure. If Denmark does not change its legislation, the Commission may refer it to the ECJ quite soon, to be the next pension taxation case decided by the ECJ after Danner and Skandia/Ramstedt cases. At the same time the United Kingdom is in the middle of a major overhaul of its pension taxation rules. So far, the UK has not indicated in which direction it wishes to move regarding contributions paid to foreign pension funds. The first consultation document remained silent on the matter. An indication of what the UK will be doing may be provided by the upcoming decision by the Inland Revenue in the Pepgo (Pan-European Pensions Group) case. In this case a group of multinationals have filed a request with the Inland Revenue to get tax deductions for contributions paid from the UK to a Dutch pension fund for a non-mobile worker who is working and residing in the UK (Arbeitsgemeinschaft..., 2005). Member States usually claim that allowing tax deduction for pension contributions paid to foreign funds would lead to losses of tax revenue. Apart from the fact that the ECJ has consistently dismissed this argument, this fear seems unwarranted. Member States may be able to develop arrangements to prevent such loss of tax revenue. As AdvocateGeneral Jacobs pointed out in his opinion on the Danner case, in line with what the Commission had said in its Pension Taxation Communication, a Member State has three ways of safeguarding the taxation of pension benefits paid out to its residents by foreign pension funds. Firstly, it can require the necessary information from the taxpayer.

Secondly, it can call on the help from the Member State where the fund is located, on the basis of the Mutual Assistance Directive of 1977. Thirdly, it can conclude a contract with the pension provider, stating that the pension provider shall provide the Member State with all the information that it needs in order to tax the future benefits. Pension providers are strongly regulated. They are meant to stay, even after our death (Hessling, M., 2000. Ahred, P. et al., 1995). They should be reliable contract partners. And in case they would breach the contract the Member State would be carrying a big stick: it could refuse any future deductions for contributions paid to the institution, thereby effectively putting it out of business. Member States should therefore not worry that allowing foreign pension institutions to provide services on their market would undermine their future tax revenues.

In conclusion, it is clear that the pension taxation landscape in Europe is changing. The two recent rulings by the ECJ and the six pending infringement cases bear witness to this. With the Skandia/Ramstedt ruling, taxpayers may claim deduction for their pension contributions paid to, for example, pan-European funds located in other Member States. If the foreign fund fulfils the same conditions as domestic funds, the 
Member State does not have the right to refuse the tax deduction. The Commission will be able to make good use of the Skandia/Ramstedt ruling in its discussions with Member States on the pending infringement cases. We seem now closer than ever to panEuropean pension funds, providing their services across borders without being hampered by tax obstacles.

In 14 out of the 15 old Member States contributions paid to pension funds by employees and/or employers enjoy some form of tax relief. In many instances this relief was only given for contributions made to domestic pension funds. Contributions to foreign funds had been excluded from the relief. This constitutes an effective barrier to the functioning on panEuropean funds: all things being equal, nobody would take out pension insurance from a foreign fund if they do not get the same tax subsidy as when paying to a domestic fund. Therefore, in April 2001, in parallel with the proposal for the Pension Fund Directive of October 2000, the European Commission issued its "Communication on the elimination of tax obstacles to the cross-border provision of occupational pensions". In the Communication the Commission presented legal analysis concluding that the above discrimination of foreign pension funds is contrary to the EC Treaty and announced that it would monitor national rules, and where necessary, begin legal proceedings before the European Court of Justice in Luxembourg (ECJ) (Langohr-Plato, U., 2005). In 2003, following-up its Communication, the Commission decided to refer Denmark to the ECJ and initiated legal proceedings against seven other Member States for alleged discrimination against foreign pension funds. Below there is an overview of the states of play.

\subsection{Belgium}

The Commission has sent Belgium a letter of formal notice and a reasoned opinion (these are, respectively, the first and second steps in the infringement procedure, under Article 226 of the EC Treaty, whereby the Commission can call on the ECJ to rule that a Member State has failed to fulfil a treaty obligation. The third step is the actual referral to the ECJ). It is not yet known whether Belgium will comply with the Commission's request.

\subsection{Denmark}

Denmark also received a letter of formal notice and a reasoned opinion, but has indicated that it does not want to change its law. The Commission has therefore referred Denmark to the ECJ (Case C-150/04, referred on 23 March 2004).

\subsection{Germany}

Germany operates various systems to provide occupational pensions. Some follow the TEE approach (contributions Taxed, fund Exempt, benefits Exempt), others follow the EET approach. When applying EET, Germany does not appear to discriminate against foreign pension funds.

\subsection{Greece}

The situation in Greece is not entirely clear, although the European Commission has not announced the opening of any infringement procedure against Greece.

\subsection{Spain}

Spain also received a formal notice and a reasoned opinion from the Commission. It has replied that it will change its legislation before 23 September 2005 - the deadline for the implementation of the Pension Fund Directive. The Commission, however, estimated that this timetable was not sufficient and has sent Spain a reasoned opinion.

\subsection{France}

France also received a formal notice and a reasoned opinion from the Commission. It, too, has replied that it will change its legislation.

\subsection{Ireland}

So far, Ireland has only received a letter of formal notice. There are signals from tax practitioners that sometimes, it may already be possible to get tax relief for contributions paid from Ireland to foreign pension funds, although the proper legal basis for such relief does not yet seem to exist. Therefore, in principle, Ireland does not appear to have any major objections to providing tax relief for cross-border contributions, and it may be willing to adapt its legislation to put matters beyond doubt.

\subsection{Italy}

To date, Italy has also received only a letter of formal notice. It is not yet clear whether, and if so, when the Commission would move to the next step of the 
infringement procedure. It is equally possible that Italy will comply with the demands of the Commission.

\subsection{Luxembourg}

Luxembourg is the only old Member State which has the TEE system for all its occupational pensions. It applies this system to contributions to both domestic and foreign funds. Its system is therefore not discriminatory.

\subsection{Netherlands}

The Netherlands allows a tax deduction for contributions paid to foreign funds. As such the Dutch system is not discriminatory. However, the Dutch antiabuse rules, when applied to cross-border contributions, may go further than is strictly necessary, especially in the light of a recent ECJ ruling on French exit taxes (Case C-9/02, de Lasteyrie du Saillant, of 11 March 2004).

\subsection{Austria}

Austria appears to treat contributions paid to foreign funds in the same way as contributions to domestic funds. Accordingly, its system does not give rise to concern.

\subsection{Portugal}

Portugal has received a letter of formal notice and a reasoned opinion from the Commission. It is not yet known whether Portugal will comply with the Commission's request and adopt legislation that will end discrimination against foreign funds.

\subsection{Finland}

Finland has rules discriminating against foreign funds, but lost its case in the ECJ (Case C-136/00 Danner of 3 October 2002, a request for a preliminary ruling by the ECJ from a Finnish judge). Pending the necessary changes of its tax law, Finland is already allowing tax deduction for contributions to foreign funds, as it does for domestic funds.

\subsection{Sweden}

Sweden is in the process of implementing the ruling by the ECJ in the Skandia/Ramstedt case (Case C422/01) of 26 June 2003. At the moment when this article was written (31 March 2004) it was not yet clear how Sweden would do that. A challenge for Sweden is that it has the ETT system, under which a tax is levied not only on the benefits, but also on the investment results and capital gains of the pension fund, the so-called yield tax. One solution for Sweden might be to conclude contracts with the foreign pension funds, allowing tax deduction for contributions paid to them, on condition that they would pay the yield tax to Sweden, just as Swedish pension funds would do. Advocate-General Jacobs of the ECJ seemed to support this solution, in his opinion on the Danner case against Finland.

\subsection{United Kingdom}

The United Kingdom is in the middle of a major reform of its pension system. The Commission has sent it a letter of formal notice. The new tax legislation needed in the framework of the broader reform seems a good opportunity to end any discrimination, but at the time of writing, it was not yet clear what the UK government intended to do with contributions paid to foreign funds.

\subsection{New Member States}

At present, no overview exists of the pension taxation systems in the new Member States, nor of any potentially discriminatory features that they might possess. The Pensions Forum, run by the European Commission's Directorate-General Employment and Social Affairs is examining whether it can establish such an overview. The new Member States need to comply with the rules of the Single Market in the same way as the old Member States. It may, therefore, be necessary that the Commission starts legal proceedings against some of the new Member States, just as it did with the old Member States.

\section{Overview}

It follows from the above that three Member States, Germany, The Netherlands and Austria, were already allowing cross-border deductions before the Commission issued its Communication of April 2001. Finland started to do so, on the basis of an ECJ ruling against it, and two Member States, Spain and France have announced that they will comply with the request of the Commission to end the discrimination against foreign funds. A number of Member States, Belgium, Ireland, Greece, Italy, Portugal, Sweden and the United Kingdom have not yet decided what to do, or their 
legal situation is unclear, but some of them can be expected to comply in the not-too-distant future.

Denmark is the only Member State which has persisted in refusing to comply with the Commission's request to end the different treatment of contributions paid to foreign funds. It will, therefore, be the next case in the area of pension taxation to be decided by the ECJ, and it is difficult to see how its rules could possibly be upheld. Denmark's main defence is expected to be that the coherence of its tax system would collapse if it were to extend national treatment to contributions paid to foreign funds. However, this argument can easily be rejected by referring to the large number of Member States that already allow cross-border deduction or have announced that they will do so in the near future, apparently without any risk for the coherence of their tax systems. The conclusion is, therefore, that for most situations, the main tax obstacle for pan-European pension funds will be eliminated after the implementation date of the Pension Fund Directive, that was by 23 September 2005. The Pension Fund Directive includes the assumptions for a cross-border activity of company pension funds. Among the existing national regulations of the setting of the systems of old age pensions the member states have to allow domestic companies in line with the Pension Fund Directive to be institution of foreign pension funds, which are licensed in other member states.

\section{References}

Arbeitsgemeinschaft für betriebliche Altersversorgung (Hrsg.). (2005) Handbuch der betrieblichen Altersversorgung, 8. Auflage, Wiesbaden.

AHREND, Peter; FÖRSTER, Wolfgang; RÖßLER, Norbert. (1995) Steuerrecht der betrieblichen Altersversorgung mit arbeitsrechtlicher Grundlegung, 4. Auflage, Köln.

BLOMEYER, Wolfgang; OTTO, Klaus. (2004) Gesetz zur Verbesserung der betrieblichen Altersversorgung, Kommentar, 3. Aufl.

HESSLING, Michael. (2000) Die Pensionsfondsrichtlinie und ihr Einfluss auf Deutschland, BetrAV: 622

LANGOHR-PLATO, Uwe. (2005) Rechtshandbuch betriebliche Altersversorgung, 3. Aufl., Recklinghausen. 